\section{TOWARDS THE PRACTICE OF FEMINIST TRANSLATION IN THAILAND}

\section{Gritiya Rattanakantadilok ${ }^{1}$}

\begin{abstract}
The practice of feminist translation as a specific approach to rendering a text in translation from English into Thai has been under-researched. This paper aims to introduce feminist translation practices developed by Canadian theorists and translators, and suggests the extent to which this approach can be applied to the practice of ideologically-motivated translation in Thailand. Feminist translation is an approach to a translation method that attacks, deconstructs or bypasses inherently misogynist language. Fidelity and equivalence in translation are not a matter of utmost importance to feminist translators. Rather, they tend to make their presence felt in the texts through various methods of textual intervention. This notion of intervention in translation is central to feminist translation practices which allow the translators of feminist works to draw the target readers' attention to linguistic transfer, translator visibility and feminist causes.
\end{abstract}

\footnotetext{
${ }^{1}$ Lecturer, Department of Languages and Linguistics, Faculty of Liberal Arts, Prince of Songkla University, Thailand.
}

Feminist translation has been advocated and practised by several Canadian theorists and translators who have developed and discussed experimental forms that are able to convey feminist ideology from French into English. However, their theories have mainly been based on the specific relationship between French and English, as well as the ideological manipulation of grammatical gender in language without this feature. This paper will therefore attempt to review the feminist strategies used in the translation from French into English and investigate the possibility of the application of feminist translation strategies in the practice of translation from English into the Thai language.

\section{Feminism in Translation Studies}

There seems to be a consensus that James S. Holmes (1924-1986) was the first pioneer of modern Translation Studies as an independent discipline (Snell-Hornby, 2006: 162). In his defining paper delivered in 1972, Holmes (1988: 67-80) envisions translation studies as a discipline in which the structure, goals and methods of the natural sciences are adopted. He presents an overall framework for the field and Toury (1995) subsequently introduces Holmes's map of Translations Studies. Munday (2012: 20) states that different areas of Holmes's map has come to the fore in the surge of translation studies since the 1970s. Snell-Hornby (2006: 162) explains that each new school of thought developed during the 1980 s went back to the new concepts created during the late 
1970s. These two decades ${ }^{2}$ saw the rise of a descriptive approach in which the theory of the literary polysystem was introduced and pursued by Toury. Together with other pioneers of this new approach, namely José Lambert, André Lefevere, Susan Bassnett and Theo Hermans, this group of scholars and their works became known as the 'Manipulation School'. In 1990, Bassnett and Lefevere introduced the term 'cultural turn', a dynamic and culturallyorientated approach that inspired a rich amount of work in fields like postcolonial and feminist translation (Munday, 2012: 21, Snell-Hornby, 2006: 164). The cultural turn is described as the abandonment of the 'scientific' linguistic approach as based on the concept of 'equivalence' (Snell-Hornby, 2006: 50). Since feminist translation places the focus on the neglected factor of power in translation, approaching translation from the perspective of gender studies can reveal the power of language in sustaining patriarchy and the power of translators in dismantling sexism in language.

For feminist translators, gender serves as a lens for the analysis of individual translation and the focus is on the linguistic components such as linguistic markers of gender that may reflect the gendered aspects of a text. Feminism in the context of translation studies focuses on gender as a socio-political category which imbues translation production. Critical studies on translation as a feminist

\footnotetext{
${ }^{2}$ During these same years, functional approaches, the skopos theory and the translatorial action theory, were developed in Germany.
}

practice have mostly been written in French and English by Canadian theorists, such as von Flotow and Simon. In several cases, neologism or the coining of a new terms has been the main outlet for the promotion of feminist ideology as part of their experimental translations. For example, a neologism in the title of Nicole Brossard's novel L'Amèr (1977) is a wordplay of three terms-mère (mother), mer (sea), and amer (bitter)—which reflects the themes of the subjugation of women to reproduction, her sufferings and her subsequent tendency to suffocate her own children (von Flotow, 1991: 75-76). The translator, Godard (1983), renders the neologism L'Amèr as follows:

The

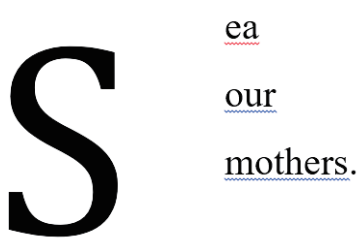

Figure 1 The English translation of the French novel's title L'Amèr

The effect of the wordplay of the title rests on the 'e muet' and the sound associations in French (von Flotow, 1991: 76). Godard's title becomes 'The Sea Our Mother' + 'Sea (S)mothers' + '(S)our Mothers'. According to von Flotow, in addition to the association of mer and mère (sea and mothers), Godard supplements the lack of the silent ' $\mathrm{e}$ ' in English by including the sour, smothering aspects of motherhood (76). She intervenes by supplementing, which is called compensation by some theorists, to 
foreground female subjectivity in the production of meaning.

The strategies in and approaches to translating texts are mostly formulated in terms of contrast between two concepts, such as Nida and Taber's binary opposition (formal equivalence and dynamic equivalence). Feminist nontraditional approaches to translation have moved away from such duality and feminist translation practices will be introduced in the following section.

\section{Feminist Translation Practices}

Exploring gender as a cultural construct and translation as a cultural transfer, feminist translation theorists focus on identity politics, positionality and the historical dimension. In tracing the relationship between Translation Studies and gender studies, Chamberlain (1988/2012: 255) surveys the prominent metaphors of translation in Europe and finds that the sexualisation of translation has been common and familiar as can be seen in the well-known adage, les belles infidels, which means translations, like women, are either beautiful or faithful. The rhyme in French makes les beaux infidels impossible. This tag has captured a cultural complicity between the issues of fidelity in translation and in marriage; fidelity is defined by an implicit contract between translation as woman and original as husband, father or author (255). The fact that the word traduction is feminine has sustained this 'double standard' that delineates writing and translating; in that the former is original and 'masculine' and the latter is derivative and 'feminine'
(255). Translation has been figured metaphorically as secondary and derivative. The metaphors disguise the secondary status of translation in the language and even though both men and women engage in translation, the male superior status in the binary opposition, original versus derivative, demotes this activity as an archetypal feminine activity (263). She proposes that feminist translators should discuss their works, both antagonistically and sympathetically, to turn the principles of translation practice into a dialogue about revising the power imbalance in translation activity (266-267).

This inferior status of translation is contested by feminist translation scholars. Barbara Godard argues that, rather than a form of reproduction, translation, in the theory of feminist discourse, serves as a form of production (Godard, 1990: 90). Godard insists that Translation is a "topos" in feminist discourse that introduces new insights to women as well as encouraging them to reflect on their relation to language (89). She confidently states that "feminist discourse is translation" (90) in that it functions as a discursive mechanism that allows translators deliberately to assume the feminine role in an act of subversive mimicry, which is "to convert a form of subordination into an affirmation and to challenge an order resting on sexual difference" (90). Feminist translators flaunt the signs of their manipulation of the text, in other words 'womanhandle' the text in translation, to affirm their critical difference and the possibility of interminable re-rereading and re-writing in their ideological execution (94). Feminist 
translators are also active participants in the creation of meaning and assert their idiosyncrasies in the form of paratextual devices such as footnotes and prefaces (94). In translating a work from the feminist writer Nicole Brossard's novel L'Amèr from French into English, Godard relies on several feminist translation strategies, including the use of graphic modes of representation and wordplay (Simon, 1996: 25-27). For example, in L'Amèr, "J'ai tué le ventre et fait éclater lamer" is rendered as "I have killed the womb and exploded the Sea/Sour mother" (27). Godard keeps the sonic and graphic quality of the homophonic pair l'amèr and la mer by relying on the alliteration in the consonant pair Sea/Sour. Her explicit graphic interventions mark the presence of the translator within the text. The English translation is punctuated with the English wordplay (the Sea/Sour mother). The reader thus is reading Brossard and Godard together. As a politically engaged translator, Godard is conscious of her influence on the text and seeks to impose it overtly.

Apart from encouraging the translators to intervene, Simon (1996) and von Flotow (2011) also attempt to make the writings of important female writers and translators whose reputations suffered visibly, by recovering their works through translation. Simon (1996) surveys notable associations between women and translation in European history. During the Renaissance, translation was the only appropriate mode of intellectual activity women could engage with because this kind of women's involvement in literary culture did not directly challenge the male control of that culture (46). During the Reformation, English women were discouraged from writing but were allowed to translate religious texts and several learned women who occupied the centre of cultural life in England published only translations (47). Margaret Tyler was a female translator in the sixteenth century who is historically important in the discussion of gender in translation because of her vigorous preface to the translation of the Spanish romance entitled A Mirrour of Princely Deeds and Knighthood (1578) (Simon, 1996: 48). In the preface, she criticized patriarchal ideology, defended the right of women to read and translate works, which are not restricted to the religious area, and encouraged women to become writers (4849). An overview of Tyler's work indicates some of the moments when translation presents itself as a socially and culturally meaningful activity for women since it has provided a point of entry for women into the literary world and allowed them to promote social and aesthetic causes through literary exchange between nations (82-83).

Also focusing on a female figure, albeit a contemporary one, von Flotow (2011) emphasises the role translation plays in adjusting and recovering the reputations of important female figures. The translation project to make visible the writings of a female author von Flotow examines is that of Ulrike Meinhof's. Only excerpts of the works of Meinhof, a German journalist, anti-militarist, opponent of nuclear armament and impassioned critic of postwar West German society, were available in English translation (135-137). The excerpts from her writings are cited out of 
context (138) and most works about Meinhof in English fix on her reputation as a terrorist and the long years in which she was a successful public intellectual in West Germany who escaped the notice of the general English public (140). Von Flotow posits that the translation project that produced the first anthology of Meinhof's writings in English in 2008 is a way of revising the history of an influential and still-much admired woman thinker (142). A wide selection of Meinhof's journalistic texts were translated completely and supplied with footnoted explanations of distant references (141), however, von Flotow admits that changes were inevitable when one of the purposes of her translations of Meinhof's writings was to make her works as readable as possible for an AngloAmerican readership of the early twentyfirst century (144). The intention of Meinhof's works is not feminist and the 'skopos' (purpose or intention) of the translation is to cast light on Meinhof's 'journalistic brilliance, her perseverance and the role she played as a humanitarian' (149). Even though in her most recent work, von Flotow does not explicitly refer to feminist translation strategies, to date she has offered the most influential translation strategies in feminist discourse, such as hijacking.

The issues of intervention and censorship in translation are central to feminist translation practices. Von Flotow (1997: 25) posits that feminist translators politically intervene in the text to dismantle misogynistic aspects of patriarchal language and assert their decision-making powers (25). Feminist translators want recognition of the work and assume responsibility for their texts (38). In so doing, she introduces three practices of feminist translation: supplementing, prefacing and footnoting, and hijacking (von Flotow, 1991: 74-80). (1) Supplementing can be seen as 'overtranslation' (75). It compensates for the differences between languages and calls for interventionist moves by the translator (75). Von Flotow uses an example from Howard Scott's translation of Louky Bersianik's L'Euguélionne (1976). The ST is 'Le ou la coupable doit être punie.' The extra ' $e$ ' is added to 'puni' to indicate that it is the woman who is punished for aborting. This cannot directly be transferred into English because of the lack of gender agreements. The translator then supplements this lack by rendering 'The guilty one must be punished, whether she is a man or a woman'. Despite the linguistic awkwardness, Scott intervenes and supplements another part of the text to demonstrate the way in which the translator of a feminist text has to turn the critique of one language into the critique of another.

(2) Prefaces and footnotes draw attention to the translation process. Feminist translators reflect on their work in a preface and emphasise their active presence in the text in footnotes. Marlene Wilderman, the translator of Nicole Brossard's La Lettre Aérienne (1985) into English entitled The Aerial Letter (1988), discusses neologisms in the preface and then highlights the use of neologisms in the footnotes.

(3) Hijacking refers to the appropriation of a text whose intentions are not necessarily 
feminist by the feminist translator (Simon, 1996: 15). Susanne de LotbinièreHarwood's translation Letters from Another (1990) of Lise Gauvin's Lettres d'une autre (1984) makes the feminine seen and heard in her translation by deliberately feminising the target text (Von Flotow, 1991: 79). Von Flotow concludes that de Lotbinière-Harwood "has in fact hijacked the text, appropriated it and made it her own to reflect her political intentions" (79).

Believing in translator visibility, both von Flotow and Simon encourage translator's intervention in producing innovative texts. Von Flotow (1997: 35) affirms that politically aware and engaged translators are conscious of their influence on the text and may seek to impose it overtly. When feminist translators introduce their work and offer explanations for their decision to intervene ideologically in the text, they are aware that their identities as gendered rewriters enter their work (35). Feminist translators reject the notion of translator's invisibility; they want recognition for their individuality (38). She concludes that translators working with feminist ethics tend to assume personal responsibility for their texts and are unwilling to disclaim their part in the text production (96). Simon (1996: 26-27) concurs, stating that the interventionism of the translator is orientated by the text itself, in that the translation follows the mode of meaning generated by the source text author and the presence of the translator is clearly marked in the text. Translators draw attention to their identities as feminists and through social or literary projects they attempt to transform sexual prejudice by manipulating grammatical gender for imaginative or political purposes in order to elucidate texts on gender terms (7). In theoretical texts, prefaces and footnotes, feminist translators affirm their role as active participants in the creation of meaning and draw attention to the process of their own work (29).

For feminist translators in the FrenchCanadian context, translation is considered to be a creative utterance which foregrounds women's identity by sheltering personal and political statements. In recent years, more works on gender in translation have been carried out and many have challenged the term 'feminist translation practices', arguing that the translation procedures employed by feminist translators are not essentially feminist since they are the same ordinary procedures both male and female translators resort to. The discussion will be taken up in the following section.

\section{Critiques of Feminist Translation Practices}

It has been argued that von Flotow's feminist practices could easily apply to both male and female translators who do not see themselves as feminists. Leonardi and Taronna (2011) attempt to prove this point by examining translated works from English into languages that are characterised by grammatical gender, namely Galician, Spanish and Italian. Their first case study is Mark Haddon's The Curious Incident of the Dog in the Night-Time (2003), which was first translated by a Galician feminist translator, María Reimóndez, and her 
feminized translation was corrected by the publisher, Moisés Barcia (Leonardi and Taronna (2011: 383-384). Her translation was not published and the publisher retranslated the book and published the translation in 2009 (383-384). Genderinclusive terms, ambiguous gender terms, marked gender terms, and sexist terms have been rendered in the four translations, which are (i) the unpublished Galician version by Reimóndez, (ii) the official Galician version by Barcia, (iii) the Spanish translation by Patricia Antón and (iv) the Italian translation by Paola Novarese. Leonardi and Taronna have studied these translations and argue that feminist translation strategies are not exclusively feminist since they resemble ordinary translation strategies, such as expansion and paratextual intervention (called 'supplementing' and 'prefacing and footnoting' respectively by von Flotow) (379). The use of a particular practice that reflects a specific ideological strategy is not necessarily associated with the feminist agenda (399).

At the macro-level, Castro (2013) discusses translation effects detected through the analysis that takes the cultural, political and literary climate of the translating culture into account. She investigates the ideological struggle emerging from the two translations of the same literary text (The Curious Incident of the Dog in the Night-Time) into Galician. Castro examines the use of inclusive language in literary translation to point out the gap between the theory and practice of translation, and the missing link between feminist approaches to linguistics and translation studies. In discussing inclusive language, Castro analyses the translations of neuters, such as sergeant, scientist, children, nurse and bloody liar, to investigate the translators' perception of some neuters as masculine and some others as feminine.

Castro concludes that the linguistic representation of women and men in translations from English into Galician is often defined by a sexist and androcentric use of language even when the source text was completely free of linguistic sexism (43). She posits that fidelity to the source text and to the author, the translator's invisibility, objectivity, and fluency are the notions behind the disparities between the two "conscious ideologically driven interventions" of both unpublished and published translators (53).

Castro argues that while there are more translation practitioners formally trained in universities, and if the objective of education is to raise an informed awareness of the powerful position the translators have in society (which lead to political and ideological consequences), a more fruitful dialogue between translation trainers and translation students is needed (53). To change the perception of translation and gender inclusivity in the wider society, interdisciplinary collaborations between translation studies, feminist studies and linguistics are a necessary combination which will help to identify, explain and justify the decisions of deliberate textual interventions during translation (53-54).

These works, which are based on translated works between Western 
languages, cannot be directly applied to the translation from French into Thai or English into Thai, most apparently because Thai is not a grammatical gender language. However, by not taking a gendered position in translating feminist works, the translators run the risk of suppressing the source text authors' political and personal identities.

\section{Putting Feminist Translation into Practice}

The language pairs discussed and experimented on by both the advocates and the critics of feminist translation are Indo-European and Romance languages in which gender markers can be employed to reveal or conceal sexism in the source and target languages. To investigate the extent to which feminist translation into a nongrammatical gender language such as Thai is possible, I will attempt a feminist translation of selected excerpts from notable feminist novels in French and English to demonstrate potential translation strategies that can be adopted by translators working with the Thai language. Examples are mainly drawn from translation problems that impose a challenge on lexical and grammatical items.

The first example discussed in this paper is the title of the French novel L'Amèr. The meanings of this newly coined word is a play on the ' $m$ ' sound: mère (mother), mer (sea) and amer (bitter). The FrenchEnglish translator manages to find words that retain both the meanings and the $/ \mathrm{m} /$ sound--'The Sea Our Mother + Sea
(S)mothers + (S)our Mothers'--which places emphasis on the $/ \mathrm{s} /$ and is still able to reiterate the themes (von Flotow, 1991: 76). The alliteration of the /s/ sound in the English translation recreates the meaning (sour and smother) along the direction given in the original, and at the same time manages to convey a similarity through graphic mode of representation (shown in Figure 1).

To translate the three meanings in the French neologism 'L'Amèr' into Thai, I propose the following translation: แม่ (mae; $\mathrm{sea})$, ทะเล (tha-le; sea), and ขมขื่น (khom khuen; bitter). If the solution is to seek words in Thai that begin with $/ \mathrm{m} /$, the word mae is naturally the obvious choice as both share the same meaning and initial consonant sound. The title 'L'Amèr' can be recreated by using the Thai words 'มัด แม่ เมาคลื่น' ( $\mathrm{mad}$, mae, mao kluen). Mad means 'tied tightly' and mao kluen means 'getting seasick' and by placing the word mae in the middle, 'the mother' is tied down to the single task of reproduction and any person who is tied would naturally feel suffocated. Further, 'the mother' is also sick of being at the same old place or in this context the sea, since she has been reduced to reproduction. Based on this translation, alliteration can be retained but some senses cannot be strictly transferred. Furthermore, the original neologism in French becomes longer in both English and Thai. The Thai translation cannot make use of the same typography as the English version does. In Figure 1, the letter ' $s$ ' is graphically more prominent than others. To draw the reader's attention 
to the consonant 'y' (m) on the book cover, a different typographical design has to be employed since Thai vowels are placed on top, below and in front of the consonants and in some words there are also intonation markers on top of the vowels. The graphic representation for the Thai translation is as follows:

\section{มัด แม่ เมาคลื่น}

Figure 2 The proposed graphic design for the Thai translation of ' $L$ 'Amèr

Another example is the translation of the work discussing the politics of abortion. The source text as quoted in the second section is 'Le ou la coupable doit être punie.' The author supplements the extra ' $\mathrm{e}$ ' on the past participle 'puni' to indicate that it is the woman who is punished for aborting. The French-English feminist translator intervenes by supplementing another part of the text in the source text and the result is: 'The guilty one must be punished, whether she is a man or a woman.' It is evident that the subtlety in the ST is not directly transferable into English which lacks gender agreements. To adapt this message in French to Thai, also a language without gender agreements, the translator may render this particular sentence as ผู้ (หญิง) ที่ทำผิดต้องถูก
ลงโทษ ${ }^{3}$. The word ying (in brackets), meaning female, is added after the prefix $p h u$, which in this context means 'the person', and to transfer the subtlety in the French source text, a typographical design in the form of parentheses is employed. At first glance, this feminised translation can be read without the inclusion of the word ying, similar to the French source text if the reader fails to notice the extra ' $e$ '. On closer examination, the word ying is blatant and the 'female' person is the prominent feature of this rendition. The word $p h u$ also means 'male' and when placed right before ying gives a sharp contrast between the two sexes. Based on this sentence alone, it can be said that the Thai translation manages to maintain some level of subtlety while the English rendition may fail to do so.

After experimenting on works in French, a language with a grammatical gender system, at word/sentence level, I will move on to works in English, a language without a grammatical gender system, similar to Thai. I will translate the works in English at a paragraph level in an attempt to investigate the compatibility of feminist translation strategies in translating literary works into Thai.

Most translated books in Thailand are from English. If feminism is to be implemented in translation, books in English will most likely be the easiest to market. The three literary works in English chosen for the experimental feminist translations are The Power (Alderman,

\footnotetext{
${ }^{3}$ The back-translation is 'The person (female) who has done wrong must be punished.'
} 
2016), The Handmaid's Tale (Atwood, 1985) and Politically Correct Bedtime Stories (Garner, 1994/2011). The Power has gained prestige since it won a major literary award. The Handmaid's Tale has not won any prizes but its author is an award-winning author. As feminists have been both positively and negatively labelled, Politically Correct Bedtime Stories is a satire on sexism.

In The Power, Naomi Alderman flips the conventional exercise of power between the sexes. Her work is the first piece of science fiction to win the Baileys Prize for Women's Fiction. Set in a dystopian future, the novel envisages a world in which teenage girls have the ability to hurt or even kill others by releasing electrical jolts from their fingertips. Alderman demonstrates what it is like for men to live as the weaker sex and the inevitability of the abuse of power by women.

The use of marked gender pronouns is foregrounded in The Power. A new religious leader is ready to feminise faith as shown in the following excerpts:

They say, 'Why do you call God "She"?'

Eve says, 'God is neither woman nor man but both these things. But now She has come to show us a new side to Her face, one we have ignored for too long.' (Alderman, 2016: 79)

Eve says, 'So I teach a new thing. This power has been given to us to lay straight our crooked thinking. It is the Mother not the
Son who is the emissary of Heaven. We are to call God "Mother". God the Mother came to earth in the body of Mary, who gave up her child so that we could live free from sin. God always said She would return to earth. And She has come back now to instruct us in her ways.' (79-80)

To show the narrative of faith being constructed to suit different agendas, the pronoun 'She' is used to refer to God. To translate this part into Thai, I have to confront the problem of conventional translation of the pronoun 'He' in reference to God in Thai. In Thai translations of the Bible, ' $\mathrm{He}$ ' is translated as phra ong (พระองค์), which is a genderinclusive term. If I decide to render 'She' in Alderman's feminist novel by employing the conventional genderinclusive term phra ong, the feminist agenda in the source text will be lost on the target text readership. I will go so far as to use 'phra ong ying' (พระองค์หญิง) to mark the shift from male God to female God in the story. By adding the word ying (woman) to signify the shift in gender, 'supplementing' strategy is put into practice as follows:

$$
\begin{aligned}
& \text { พวกเธอถามอีฟ “เหตุใดท่านจึง } \\
& \text { เรียก พระเจ้าด้วยการ ใช้สร ร พ นาม } \\
& \text { พระองค์หญิง” } \\
& \text { อีฟตอบว่า “พระเป็นเจ้าไม่ได้ } \\
& \text { เป็นสตรีหรือบุรุษเพศ แต่เป็นได้ทั้งสอง } \\
& \text { เพศ เพียงแต่เวลานี้พระองค์หญิงได้เสด็จ }
\end{aligned}
$$


มาโปรด ให้พวกเราได้เห็นพระพักตร์อีก ด้านหนึ่งของพระองค์ ซึ่งเป็นด้านที่เราไม่ ใส่ใจมาเป็นเวลาเนิ่นนาน"

อีฟกล่าวว่า “ฉันสอนสิ่งใหม่
พ ลัง ที่ พ วกเราได้ม านั้น จะทำให้
แนวความคิดของเราหายผิดเพี้ยน พระ
มารดาต่างหาก ไม่ใช่พระบุตร ที่เป็นทูต
สวรรค์ เราต้องเรียกพระเจ้าว่า “พระ
มารดา” พระมารดาผู้เป็นพระเจ้าเสด็จ
มายังโลกในร่างของมารี ผู้ซึ่งเสียสละเพื่อ
ลูก เพื่อให้พวกเราได้พ้นบาป พระผู้เป็น
เจ้าตรัสอยู่เสมอว่าพระองค์หญิงจะหวน
กลับมายังพื้นโลก และพระองค์หญิงก็ได้
กลับมาเพื่อประทานคำสอนตามวิถีทาง
ของพระองค์เอง”

Assuming the position of a feminist translator, I can also explain my decision in a preface or footnote to draw attention to my translation process.

Another acclaimed work is The Handmaid's Tale which is set in Gilead, a patriarchal theocracy that takes over the US in Margaret Atwood's 1985 novel. In the book, handmaids are the remaining fertile women who are forced to have sex with powerful men and bear their children. This novel has been translated into more than forty languages (Atwood, 2017).

Atwood has coined the new terms 'Unwoman' and 'sororize' in her work to demonstrate the different ways in which women are suppressed. The term 'sororize' is coined to point out a void in the English language and Atwood's prose will be quoted for the purpose of the present exposition as follows:

The Marthas are not supposed to fraternize with us.

Fraternize means to behave like a brother. Luke told me that. $\mathrm{He}$ said there was no corresponding word that meant to behave like a sister. Sororize, it would have to be, he said. From the Latin. (Atwood, 1985: 11)

When the term 'sororize' is juxtaposed with 'fraternize', the source text readership can clearly see the linguistic sexism embedded in English. In Thai, the term pha-ra-da (ภราดา) means 'a brother'. To translate 'fraternize', the translator can coin a new term phruet-ti pha-ra-da (พฤติ ภราดา) so that the word phruet-ti (meaning 'to behave', a borrowing from Sanskrit) can also be used for the translation of 'sororize' as phruet-ti pha-khi-ni (พฤติ ภคินี). These experimental renderings constitute an effort to deconstruct linguistic sexism at a micro-level as shown in the following Thai translation:

$$
\text { กลุ่มหญิงรับใช้หรือพวกมาร์ธา }
$$

ไม่ควรมีพฤติภราดากับพวกเรา

$$
\text { ลุคบอกว่าคำว่า “พฤติภราดา" }
$$

แปลว่ามีพฤติกรรมเหมือนผู้ชาย แต่ไม่มี 


\section{คำศัพท์ลักษณะเดียวกันที่จะใช้บรรยาย \\ การกระทำที่ว่า “มีพฤติกรรมเหมือน \\ ผู้หญิง” ถ้าจะคิดคำใหม่ก็อาจจะได้คำว่า \\ “พฤติภคินี” จากภาษาสันสกฤต}

I, as the translator, have to change the source text phrase 'from the Latin' to the phrase 'from the Sanskrit' in the translation to reflect the true nature of my newly coined words. Interference with the text is in play. I have to adapt the message in English to the Thai language to show how the Thai language can be sexist. Having said that, since neither phruet-ti pha-ra-da nor phruet-ti pha-khi-ni exist in the Thai language, I fail to reveal any sexist aspect. To coin new terms using available prefixes and suffixes in the target language, I also run the risk of removing the target text readership from the geographical setting of the story. The setting is in the US and the characters speak English, which borrows from Latin. It is odd for American characters to be familiar with Sanskrit words. Furthermore the translation sounds unnatural in Thai. The idiomatic rendition of the first line is:

\section{กลุ่มหญิงรับใช้หรือพวกมาร์ธา ไม่ควรมาสุงสิงกับพวกเรา}

If the aim is to give the readership a natural, idiomatic expression, one may resolve to use the word sung sing to represent the sense of the word 'fraternize'. To reduce 'fraternize' into one Thai word sung sing, the sexist aspect of the English language is completely eradicated in the translation. By not showing any trace of sexism, the translator would fail to turn the critique of English language into the critique of Thai language. Given that after coining new terms in Thai, I still cannot compensate for linguistic differences between this language pair. What I have managed to accomplish is that, while I have not completely ignored the traditional view on the importance of 'fidelity' and equivalence in translation, I have attempted to confront a patriarchal word 'fraternize'.

Another neologism in Atwood's work is 'Unwoman'. It is used in the story to condemn women as follows:

Sometimes, though, the movie would be what Aunt Lydia called an Unwoman documentary. Imagine, said Aunt Lydia, wasting their time like that, when they should have been doing something useful, back then the Unwomen were always wasting time. They were encouraged to do it. (118)

The translator can coin a new term $a$-sa-tri (อสตรี). The prefix 'อ' (pronounced /a/) is placed in front of a noun or an adjective to negate the quality or state contained in the word, similar to the prefix 'un' in English. I have translated the excerpt as follows:

$$
\begin{aligned}
& \text { แต่บ างครั้ง ป้าลิ เดี ยก็ เรี ยก } \\
& \text { ภาพยนตร์เรื่องนี้ว่าสารคดีอสตรี ป้า } \\
& \text { ลิเดียบอกว่าลองคิดดูสิ เอาเวลาไปทำเรื่อง } \\
& \text { ไร้สาระแบบนั้น ทั้งๆ ที่ควรเอาเวลาไปทำ }
\end{aligned}
$$




\section{อะไรที่เป็นประโยชน์ สมัยก่อนพวก อสตรีทำแต่อะไรที่ไร้สาระ เพราะว่ามีคน ส่งเสริม}

Atwood lexicalizes the word 'Unwoman' in English by applying the same grammatical rule for this neologism's plural form 'Unwomen'. In Thai, a singular noun can be turned into a plural noun by adding the word 'พวก' (phuak). Based on these two neologisms in Atwood's work, 'sororize' and 'Unwoman', when the newly coined term is not associated with words that are coined based on etymology ('fraternize' and 'sororize), a different level of translator's interference with the text is called for.

The works by Alderman and Atwood are feminist works as the authors willingly and openly have claimed in numerous interviews and articles. A work that is not inherently feminist but a satire of politically correct language is the work by the male author. James Finn Garner's Politically Correct Bedtime Stories was first published in 1994 and the expanded edition featuring a new story was published in 2011. Garner adapts fairy tales and fables by satirising the language and politics of political correctness. His hyperbole is most evident in his penchant for neologism.

In his revisionist tales, the nouns 'woman' and 'women' are changed into 'wommon' and 'womyn' to dislodge patriarchy. The prefix 'wo' is added to the word 'man' to imply that a woman is an extension of a man, which is consistent with the Bible. Garner consistently uses 'wommon' and 'womyn' in his revisionist tales as follows:

After the bears had left, a melanin-impoverished young wommon emerged from the bushes and crept up to the cottage. (Garner, 1994/2011)

When choosing Thai words for 'woman', we see that there are many possible choices and the most commonly used words are phu ying (ผู้หญิง) and sa-tri (สตรี). Some would argue that theThai language is in one regard sexist because the word ying follows the word $p h u$, which also means 'male', to form a new word to refer to an opposite sex. On the other hand, one can argue that the word sa-tri, which is not Thai but a borrowing from Sanskrit, is a non-sexist term, seeing as it is not an extension of the word burut (บุรุษ), but also a borrowing from Sanskrit, used for calling a male person. I would solve this translation problem by typography as follows:

$$
\begin{aligned}
& \text { เมื่อหมีไปแล้ว ผู้หญิงที่พร่อง } \\
& \text { เมลานินเดินออกมาจากพุ่มไม้และย่องไป } \\
& \text { ที่กระท่อม }
\end{aligned}
$$

The word phu is juxtaposed with ying and $p h u$ is italicized to draw the reader's attention to both phu and ying. Boldface type will also be employed for the plural form 'womyn' when translated into Thai. Based on this solution, it is clear that the author's intention to avoid using any sexist 
terms at all costs is lost in the Thai language.

This is probably the most difficult translation problem to solve out of all the works discussed so far. The lack of sexism in the target language renders difficult the task to foreground neologisms of this satirist work in the translation. To find a way of addressing sexism in the source language, prefacing and footnoting can be adopted to draw attention to the patriarchal aspect of the English language. Typographical warnings, italic and boldfaced words, are textual intervention while prefacing and footnoting are paratextual interventions. For neologisms whose constructions are derived from both old and new graphemes and morphemes, the Thai translator has to intervene both textually and paratextually to retain both satirical and feminist aspects in the TT. The ideologically motivated translator has to employ as many translation strategies as possible to confront the linguistic representation of women and men in the source text.

The experiment on translating feminist works at word/sentence and paragraph levels from French and English into Thai reveals that feminist translation can be applied in the Thai language but for the translator to remain visible and to make a feminine voice heard, s/he has to apply all translation procedures at hand. Even after the translator has employed all interventionist devices, meanings may not be completely transferable.

\section{Conclusion}

To conclude that feminist translation practices have not been adopted at all in Thai literary works would be misleading. However, the practice of some translators which reflect a specific ideological strategy may not be associated with any feminist agenda and even if it is, some translators would not admit that they are feminists. The case in point is that of the translators of Sepha rueang Khun Chang Khun Phaen into English, Baker and Pasuk (2010/2012). They did not see themselves as feminists. They stated clearly that they intervened in the translation to reverse the obvious bias of the nineteenth century (Gritiya, 2016: 238).

Baker and Pusuk's intervention reflects some gendered aspects of the source texts. The main female character, Wanthong, does not even deserve any mention in the title of the work, however, the translators did not find a way of dismantling this sexist aspect in their translation of the title. Sepha rueang Khun Chang Khun Phaen is not a feminist text and if Baker and Pasuk see themselves as feminist translators, they have to "hijack" the text by deliberately feminising the target text. To a degree, Baker and Pasuk "hijacked" the text by interweaving different segments from the Wat Ko edition into their translation to make the feminine (female characters) seen and heard and they managed to feminise the target text by replacing the most gripping scene featuring the masculine (Khun Phaen) so that the feminine (Wanthong) appears more prominent in the poem (196-197). 
However, Baker and Pasuk's translation is for an English readership. Gender awareness in translation should be brought into the discussion through literary translations from French and English into Thai. If feminist works in these languages are translated into Thai, translators' interventions and their critique of the Thai language would open another area of inquiry, which will then contribute to translation studies, which is an emerging field in Thailand. Experimental work of this nature in the French-Thai and EnglishThai language pairs would certainly attract interaction and collaboration between academics from different fields, namely linguistics, sociology and anthropology.

As Leonardi and Taronna (2011) and Castro (2013) argue, prefacing and footnoting is not exclusively a feminist translation procedure; this procedure is employed in translated works that do not foreground gender. The only practice that is considered to be essentially feminist is hijacking, the appropriation of a text whose intentions are not necessarily feminist by the feminist translator. I argue that all three practices, if employed, are still feminist if they serve to transform the fact of gender into a social and literary project.

Translators on the Thai literary scene should produce work that is experimental and constitutes an effort to deconstruct the conventional language perceived as inherently misogynist. In literary works in French and English, neologism has been developed and the marked gender pronoun is used to parody and attack conventional and prescriptive 'patriarchal language'.
Translators of feminist works into Thai have to undo such language for women's words to be heard, develop and find a space. Translators of these works will have to be in a dialogue with the social and political culture that may think that feminism is a dirty word. They will have to draw attention to their identities as feminist translators. Thai translators will need to be both visible and interventionist to engage in feminist linguistic activism. Awareness of the vital role that non-sexist language plays can be raised through innovative writings and translations. Feminist linguistic interventions can and should be adopted when writing (or rewriting) a translated text in Thai, regardless of the degree of success in terms of transference, in the belief that translation practice can only stand to gain from new approaches.

\section{References}

Alderman, Naomi. 2016. The Power. London: Penguin Random House.

Atwood, Margaret. 1985/2017. The Handmaid's Tale. London: Penguin Random House.

Brossard, Nicole. 1983. These OurMothers. Translated by Barbara Godard. Toronto: Coach House Press.

Castro, Olga. 2013. Talking at crosspurposes? The missing link between feminist linguistics and translation studies. Gender and Language (Equinox Publishing): 35-58. 
Chamberlain, Lori. 1988/2012. Gender and the Metaphorics of Translation. The Translation Studies Reader, edited by Lawrence Venuti. New York:

Routledge: 254-268

Garner, James Finn. 1994/2011. Politically Correct Bedtime Stories. London: Souvenir Press.

Godard, Barbara. 1990. Theorizing Feminist Discourse/Translation. Translation, History, Culture, edited by Susan Bassnet and Andre Lefevere. London: Pinter Publishers: 87-96.

Leonardi, Vanessa, and Annarita Taronna. 2011. Translators vs Translatresses' Strategies: Ethical and Ideological Challenges. MonTI. Monografías de Traducción e Interpretación 3: 377 402.

Munday, Jeremy. 2012. Introducing Translation Studies. London and New York: Routledge.

Rattanakantadilok, Gritiya. 2016. Translating the tale of Khun Chang Khun Phaen: representations of culture, gender and Buddhism. Doctoral disseratation, University of Leeds.

Simon, Sherry. 1996. Gender in Translation: Cultural Identity and the Politics of Transmission. London: Routledge.

Snell-Hornby, Mary. 2006. The Turns of Translation Studies. Amsterdam: John Benjamins B.V. von Flotow, Luise. 1991. Feminist Translation: Context, Practices, Theories. TTR (Association canadienne de traductologie) 4. 2: 69-84.

von Flotow, Luise. 1997. Translation and Gender: Translating in the 'Era of Feminism'. Manchester: St. Jerome Publishing.

von Flotow, Luise. 2011. Ulrike Meinhof: De-fragmented and Remembered. Translating Women. Ottawa: University of Ottawa Press: 135-150. 